\title{
Allozyme Variation in Different Species of Deciduous Oaks From Northwestern Italy
}

\author{
By P. Belletti ${ }^{1,3}$, S. Leonardi ${ }^{2}$, I. Monteleone ${ }^{1}$ and P. Piovani ${ }^{2}$
}

(Received $1^{\text {st }}$ December 2004)

\begin{abstract}
Allozyme variation was studied by electrophoresis at 11 loci in 14 populations of Quercus petraea, Q. robur, $Q$. cerris and $Q$. pubescens from Piedmont, northwestern Italy. The aim of the work was to characterize the genetic resources and to suggest effective measures for in situ preservation of biodiversity.

As expected, most of the genetic variability was found at the within population level, and genetic differentiation accounted for about $14 \%$ of it. The study confirmed the low level of genetic variability among the species studied: only $Q$. cerris populations could be clearly distinguished. $Q$. pubescens could be separated from $Q$. petraea and $Q$. robur using Principal Coordinate Analysys. The latter was also found to be useful for separating $Q$. petraea and $Q$. robur populations. However, in mixed populations, the differentiation between the latter species was similar to that scored among populations belonging to the same species. A significant deviation from random mating was observed, although it was variable among species: $Q$. pubescens had the highest value for the inbreeding coefficient $\mathrm{F}_{\mathrm{IS}}(0.159)$.
\end{abstract}

Key words: Allozyme variation, genetic diversity, heterozygosity, population differentiation, Quercus spp.

\section{Introduction}

Deciduous oaks are long-lived species producing timber of high value. In the past they were among the most common forest trees in the Po Valley (Northern Italy). At present, agricultural activities, environment deterioration and tree cutting have fragmented populations of Quercus robur L. (English oak) and Quercus petraea (Matt.) Liebl. (Sessile oak) into smaller and more isolated breeding groups with potentially restricted gene flow between them (KREMER et al., 2002a; PETIT et al., 2002; BRUSCHI et al., 2003; MUIR et al., 2004). The natural ranges of $Q$. robur and $Q$. petraea largely overlap, although the former is mainly found in rich and humid sites in the lowlands, while the latter is better suited to the dryer and warmer sites at medium altitude (KLEINSCHMIT, 1993). Moreover, Q. robur is considered to be a pioneer species that can be progressively replaced by Q. petraea (BACILIERI et al., 1996b). Quercus cerris L. (European Turkey oak) prefers the habitat of the hilly regions of Apennines chain, while Quercus pubescens

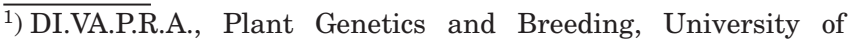
Turin, Grugliasco, Italy.

$\left.{ }^{2}\right)$ Department of Environmental Sciences, University of Parma, Parma, Italy.

$\left.{ }^{3}\right)$ Author for correspondence: Piero Belletti, University of Turin, DI.VA.P.R.A. - Plant Genetics and Breeding, via Leonardo da Vinci 44, 10095 Grugliasco, Italy, tel. +39 011 6708804, fax +39011 2368804, E-mail: piero.belletti@unito.it
Willd. (Pubescent oak) is a more frugal species usually found on sunny and dry slopes at medium-high altitudes (FENAROLI and GAMBI, 1976).

According to MANOs et al. (1999) the species considered in this study belong to two phylogenetically distinct subgenera: subg. Lepidobalanus (Q. petraea, Q. robur and $Q$. pubescens, also known as white oaks) and subg. Cerris (Q. cerris). However, the systematic relationships between different species of the genus Quercus still have to be clarified, due to the frequent hybridisation between taxa (NIxon, 1993; MuIR et al., 2000; PETIT et al., 2002). In particular, hybrid introgression across species has been demonstrated, mainly by morphometric studies (RUSHTON, 1993; BRUSCHI et al., 2000), between $Q$. petraea and $Q$. robur, and extensive interspecific gene flow has also been reported in mixed stands of the same species. $Q$. petraea preferentially pollinates $Q$. robur, whereas the reciprocal crosses seldom occur (BACILIERI et al., 1993; BACILIERI et al., 1994; STREIFF et al., 1999). Isozyme analysis and DNA analysis could make an important contribution to improving our knowledge on this aspect, identifying markers useful for species differentiation. Results so far have been only partially encouraging (ZANETTO et al., 1994; KLEINSCHMIT et al., 1995; SAMUEL et al., 1995; BACILIERI et al., 1996; COART et al., 2002). Recently, several species-specific RAPD markers have been identified and proposed as a tool to detect interspecific hybridisation between $Q$. robur and Q. petraea (SAMUEL, 1999).

In oaks, isozymes have also been used to study the level and distribution of genetic variation in populations. In general, oaks were proven to be more variable than other broad-leaved and widespread forest species. In addition, genetic variation was found to be high within populations but low among populations, and a significant deficit of heterozygotes was observed in most populations studied (MÜLLER-STARCK and ZIEHE, 1991; KIM et al., 1993; MÜlLeR-StARCK et al., 1993; ZANETTO et al., 1993; MATTILA et al., 1994; BACILIERI et al., 1995; SAMUEL et al., 1995; ZANETTO and Kremer, 1995; KREMER and ZANetTo, 1997: Le CoRRe et al., 1998; GömÖRY et al., 2000; FINKELDEY and MÁTYÁs, 2003).

The present study was carried out to describe the genetic variation and differentiation at isozyme loci within and between 14 natural populations of four deciduous oak species from northwestern Italy. The effect of intraspecific gene flow on the genetic structure of $Q$. petraea and $Q$. robur has been evaluated, and general versus local differentiation between two locations where both species were sampled has been quantified. The data obtained are of basic importance for the characterisation of genetic resources and for the adoption of practical and effective measures for in situ preservation 
of biodiversity (BRUSCHI et al., 2003). Genetic structure could be used to understand mating system patterns, that can be influenced both by isolation of stands and low densities (LEDIG, 1988; 1992; ElLSTRAND and ELAM, 1993; Dutech et al., 2005), and extent of genetic distinctness of populations. Furthermore, aim of the study was also to assess if our markers are useful to distinguish different oak species. This is particularly important for $Q$. petraea and $Q$. robur, giving the high levels of hybridisation between species and the difficulties to identify them by morphological and genetic characters (KREMER et al., 2002b; PONTON et al., 2004).

\section{Materials and Methods}

\section{Plant material and sampling}

Fourteen natural oak populations representative of the locations where the species grow in Piedmont were sampled, including 5 populations of $Q$. petraea and $Q$. robur and 2 of $Q$. cerris and $Q$. pubescens. Species identity of the collected material was verified on the basis of leaf characteristics, mainly length of peduncule and relative height of maximum width (DUPOUEY and BADEAU, 1993).

The collection sites are situated in Piedmont, northwestern Italy. They are shown in Figure 1. The populations were chosen on the basis of preliminary observation regarding the possession of requisites for inclusion in the official Italian list od seed stands: they are native,

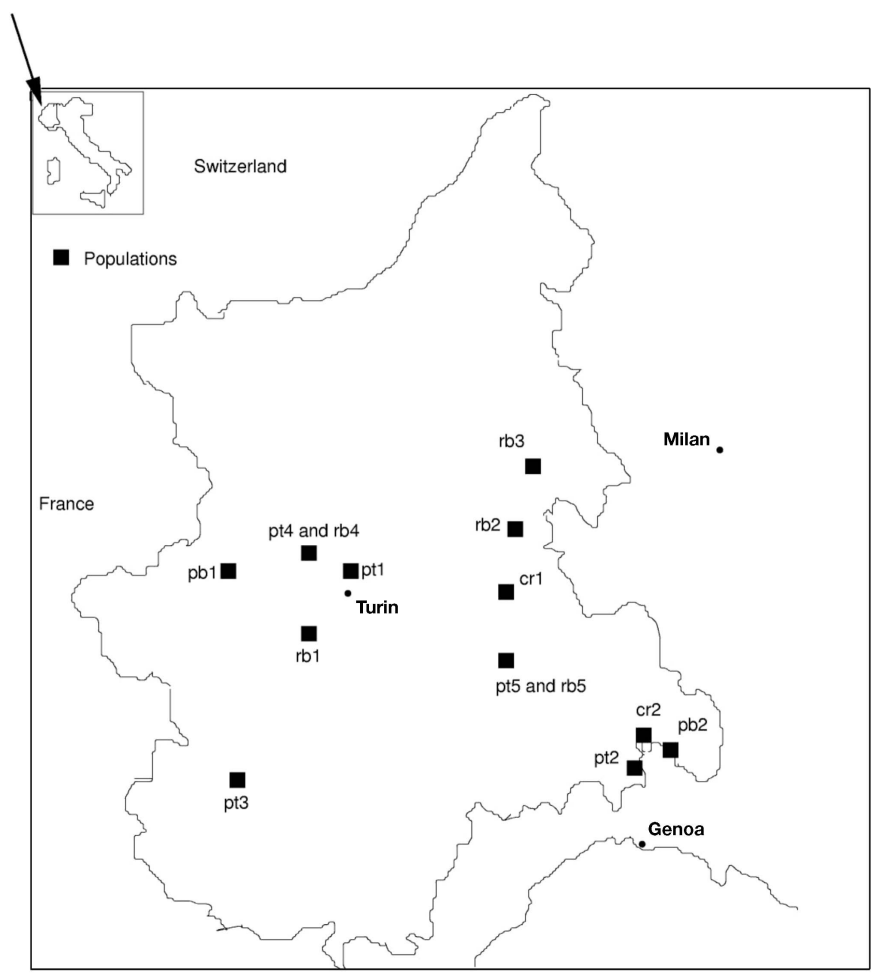

Figure 1. - Sites of studied oak populations. Quercus petraea: pt1 Castagneto Po, Torino; pt2 Capanne Marcarolo, Alessandria; pt3 Sampeyre, Cuneo; pt4 La Mandria, Torino; pt5 Rocchetta Tanaro, Asti. Q. robur: rb1 Stupinigi, Torino; rb2 Bosco della Partecipanza, Vercelli; rb3 Lame del Sesia, Vercelli; rb4 La Mandria, Torino; rb5 Rocchetta Tanaro, Asti. Q. cerris: cr1 Rolasco, Alessandria; cr2 Gavi Ligure, Alessandria. Q. pubescens: $p b 1$ Chianocco, Torino; $p b 2$ val Borbera, Alessandria. large enough to prevent inbreeding phenomena and isolated from other stands of lower quality or artificial origin. The trees also possess good silvicoltural and production characteristics. The populations contain different age classes and natural regeneration was observed in all of them. All the selected populations grow in mixed forest, with $Q$. cerris, $Q$. pubescens and $Q$. petraea representing the dominant species. $Q$. robur is present at a lower density. In two locations, the stands of $Q$. petraea are adjacent, and even overlapping with those of Q. robur (populations pt4 with rb4 and pt5 with rb5 respectively). However, in these locations material has not been sampled in the overlapping areas and only individuals with morphological characteristics peculiar to each species have been sampled.

Isozyme analysis was carried out on winter buds from at least 75 adult non-adjacent plants, chosen at random over a 2-5 ha area. Buds were collected in November to February, and were kept at $4^{\circ} \mathrm{C}$ until analysis (within a period no longer than two weeks).

\section{Electrophoretic methods}

Enzymes were separated by horizontal gel electrophoresis in $11 \%$ hydrolysed potato starch (Sigma S4501). Eleven enzyme systems were studied (acronyms and Enzyme Commission number are reported between brackets): alcohol dehydrogenase (Adh, 1.1.1.1), NADHdiaphorase (Dia, 1.6.4.3), glutamate dehydrogenase (Gdh, 1.4.1.2), glutamate oxaloacetate transaminase (Got, 2.6.1.1), glyceraldehyde 3-phosphate dehydrogenase (G3pdh, 1.2.1.12), isocitric dehydrogenase (Idh, 1.1.1.42), malate dehydrogenase (Mdh, 1.1.1.37), phosphogluconate dehydrogenase (6Pgdh, 1.1.1.44), phosphoglucose isomerase (Pgi, 5.3.1.9), phosphoglucomutase (Pgm, 5.4.2.2), shikimic dehydrogenase (Skdh, 1.1.1.25). The number of scored alleles was 2 for G3pdh, 3 for Adh, Dia, Gdh, Got, Mdh, Pgm, Skdh and 4 for Idh, 6Pgdh, Pgi.

Two different buffer systems, differing only in $\mathrm{pH}$, were used depending on the enzyme system to be analysed: tris-citrate 1 (TC1, Electrode buffer: tris 0.135 $\mathrm{M}$ and gel buffer: tris $0.056 \mathrm{M}$, titrated at $\mathrm{pH} 7.0$ with $\mathrm{HCl}$ ) for Adh, Gdh, Got, G3pdh, Pgm, Skdh and Tris-citrate 2 (TC2, pH 7.8) for Dia, Idh, Mdh, 6Pgdh, Pgi.

Approximately $100 \mathrm{mg}$ of tissue from descaled buds was ground in $100 \mu \mathrm{l}$ of extraction buffer ( $0.1 \mathrm{M}$ Tris, 2.7 mM EDTA di-sodium salt, $0.1 \mathrm{M}$ ascorbic acid, $6.5 \mathrm{mM}$ dithiothreitol, supplemented with $1 \mathrm{mg} / \mathrm{ml}$ PVP-40 and $0.5 \%$ mercaptoethanol, and titrated at $\mathrm{pH}$ 7.2). The homogenate was absorbed onto filter-paper wicks and loaded onto gel slabs. Gels were run at 12 (TC1) or 8 (TC2) $\mathrm{Vcm}^{-1}$ for 30 minutes before removing the wicks, and then left overnight.

Enzyme staining followed the procedures given by WENDEL and WEEDEN (1989), except for Dia (WEEDEN, 1984). In staining for Adh, Idh and Pgi, $5 \mathrm{mg}$ of NADP were used instead of NAD, whereas in staining for Adh and Gdh, respectively, $2 \mathrm{ml}$ of ethanol and $1 \mathrm{~g}$ of L-glutamate sodium salt were used.

The statistically identified loci were indicated by capital letters following the enzyme acronyms: the most 
anodal zone was designated with $\mathrm{A}$. Within a single zone of activity the allozyme variants were labelled according to their mobility relative to the most common allele, which was labelled $100(\mathrm{Rm})$.

\section{Data analysis}

Population genetics parameters were estimated using the Biosys-1 program (SwOFFord and SElander, 1981). Deviations from Hardy-Weinberg equilibria were tested by $\chi^{2}$ and Fisher exact tests, pooling genotypes whenever expected frequencies were less than 0.05 . The following multilocus measures of gene diversity were calculated: mean observed and expected heterozygosity, average number of alleles per locus, percentage of polymorphic loci (by convention, loci were considered polymorphic if the frequency of the most common allele did not exceed 0.99). Genetic distances were calculated according to NEI (1978).

Genetic differentiation among populations was measured as $\theta$, according to WEIR and COCKERHAM (1984).
Standard deviation of $\theta$ was estimated by a jackknife procedure over loci. Principal Coordinate Analysis (PcoA) was carried out only on the matrix of Nei genetic distances using the cmdscale (VEnABLES and RIPLEY, 1997) function of the $R$ statistical (R DEvelopment CoRE TEAM, 2004). Linkage disequilibrium was calculated with a permutation test (WEIR, 1996) of 1000 times each by the GDA computer package program. Distinction between general $\left(C_{g}\right)$ and local differentiation $\left(C_{l}\right)$ between $Q$. robur and $Q$. petraea was calculated according to BoDEnes et al. (1997). Local species differentiation represents the variation of species differentiation from one region to another, and it is seen as an interaction between species and region.

\section{Results}

Eleven enzyme systems were studied, each with one region of activity, and all loci were found to be polymorphic. In general, the observed banding patterns were in

Table 1. - Allele frequencies and expected heterozygosity $\left(\mathrm{H}_{\mathrm{e}}\right)$ in the 14 oak populations under study.

\begin{tabular}{|c|c|c|c|c|c|c|c|c|c|c|c|c|c|c|c|}
\hline \multirow[b]{2}{*}{ Locus } & \multirow[b]{2}{*}{ Allele } & \multicolumn{14}{|c|}{ Population } \\
\hline & & pt1 & pt2 & pt3 & pt4 & pt5 & rb1 & rb2 & rb3 & rb4 & rb5 & cr1 & cr2 & pb1 & pb2 \\
\hline \multirow[t]{4}{*}{ Adh } & A-124 & .076 & .053 & .203 & .136 & .200 & .000 & .000 & .030 & .064 & .025 & .000 & .043 & .125 & .104 \\
\hline & $A-100$ & .822 & .856 & .608 & .864 & .757 & .758 & .896 & .948 & .779 & .950 & .640 & .761 & .833 & .885 \\
\hline & A-88 & .102 & .091 & .189 & .000 & .043 & .242 & .104 & .022 & .157 & .025 & .360 & .196 & .042 & .010 \\
\hline & $H_{\mathrm{e}}$ & .311 & .258 & .557 & .237 & .388 & .370 & .188 & .101 & .368 & .097 & .466 & .385 & .291 & .207 \\
\hline \multirow[t]{4}{*}{ Dia } & A-122 & .397 & .613 & .701 & .300 & .133 & .066 & .199 & .048 & .110 & .133 & .000 & .000 & .074 & .067 \\
\hline & $A-100$ & .532 & .387 & .201 & .700 & .867 & .934 & .801 & .935 & .884 & .867 & .866 & 1.000 & .657 & .767 \\
\hline & A-76 & .071 & .000 & .098 & .000 & .000 & .000 & .000 & .017 & .006 & .000 & .134 & .000 & .269 & .167 \\
\hline & $H_{\mathrm{e}}$ & .559 & .478 & .461 & .423 & .232 & .124 & .321 & .123 & .209 & .232 & .235 & .000 & .495 & .384 \\
\hline \multirow[t]{4}{*}{ Gdh } & A-120 & .167 & .212 & .025 & .129 & .008 & .042 & .000 & .110 & .068 & .091 & .000 & .000 & .144 & .000 \\
\hline & $A-100$ & .778 & .636 & .900 & .550 & .719 & .842 & .770 & .797 & .636 & .773 & .287 & .364 & .615 & 1.000 \\
\hline & A-86 & .056 & .152 & .075 & .321 & .273 & .116 & .230 & .093 & .296 & .136 & .712 & .636 & .240 & .000 \\
\hline & $H_{e}$ & .367 & .532 & .185 & .582 & .412 & .279 & .357 & .348 & .507 & .379 & .415 & .468 & .548 & .000 \\
\hline \multirow[t]{4}{*}{ Got } & B-122 & .286 & .125 & .144 & .112 & .114 & .082 & .000 & .038 & .045 & .174 & .314 & .107 & .075 & .000 \\
\hline & B-100 & .714 & .773 & .856 & .851 & .886 & .820 & .919 & .962 & .932 & .758 & .686 & .750 & .925 & 1.000 \\
\hline & B-78 & .000 & .102 & .000 & .037 & .000 & .098 & .081 & .000 & .023 & .068 & .000 & .143 & .000 & .000 \\
\hline & $H_{e}$ & .411 & .379 & .249 & .264 & .203 & .314 & .150 & .073 & .130 & .394 & .436 & .410 & .141 & .000 \\
\hline \multirow[t]{3}{*}{ G3pdh } & $A-100$ & 1.000 & 1.000 & 1.000 & 1.000 & 1.000 & 1.000 & 1.000 & 1.000 & 1.000 & 1.000 & 1.000 & 1.000 & .974 & .967 \\
\hline & A-94 & .000 & .000 & .000 & .000 & .000 & .000 & .000 & .000 & .000 & .000 & .000 & .000 & .026 & .033 \\
\hline & $H_{e}$ & .000 & .000 & .000 & .000 & .000 & .000 & .000 & .000 & .000 & .000 & .000 & .000 & .052 & .065 \\
\hline \multirow[t]{5}{*}{ Idh } & A-136 & .032 & .000 & .000 & .115 & .000 & .000 & .000 & .000 & .007 & .000 & .146 & .000 & .000 & .000 \\
\hline & A-122 & .145 & .058 & .235 & .269 & .097 & .271 & .234 & .310 & .197 & .230 & .134 & .151 & .010 & .000 \\
\hline & A-100 & .815 & .758 & .647 & .615 & .903 & .681 & .766 & .627 & .553 & .738 & .720 & .849 & .960 & 1.000 \\
\hline & A-94 & .008 & .183 & .118 & .000 & .000 & .048 & .000 & .063 & .243 & .032 & .000 & .000 & .030 & .000 \\
\hline & $H_{e}$ & .317 & .391 & .516 & .540 & .176 & .464 & .362 & .511 & .600 & .405 & .448 & .260 & .078 & .000 \\
\hline \multirow[t]{4}{*}{ Mdh } & B-124 & .151 & .187 & .101 & .150 & .153 & .061 & .097 & .048 & .013 & .061 & .310 & .112 & .048 & .143 \\
\hline & B-100 & .825 & .806 & .855 & .707 & .822 & .932 & .879 & .798 & .981 & .931 & .488 & .888 & .731 & .847 \\
\hline & B-86 & .024 & .007 & .044 & .143 & .025 & .007 & .024 & .154 & .006 & .008 & .202 & .000 & .221 & .010 \\
\hline & $H_{\mathrm{e}}$ & .298 & .318 & .259 & .460 & .303 & .128 & .219 & .339 & .037 & .129 & .633 & .201 & .419 & .265 \\
\hline \multirow[t]{5}{*}{ 6Pgdh } & B-132 & .000 & .000 & .000 & .000 & .000 & .000 & .000 & .000 & .000 & .007 & .073 & .065 & .010 & .000 \\
\hline & B-124 & .156 & .331 & .217 & .111 & .000 & .042 & .234 & .197 & .147 & .059 & .293 & .022 & .029 & .049 \\
\hline & B-100 & .844 & .645 & .768 & .794 & .970 & .888 & .766 & .803 & .853 & .846 & .634 & .913 & .923 & .951 \\
\hline & B-84 & .000 & .024 & .014 & .095 & .030 & .070 & .000 & .000 & .000 & .088 & .000 & .000 & .038 & .000 \\
\hline & $H_{\mathrm{e}}$ & .265 & .478 & .365 & .351 & .058 & .120 & .361 & .319 & .252 & .276 & .513 & .163 & .147 & .094 \\
\hline \multirow[t]{5}{*}{ Pgi } & B-124 & .059 & .031 & .053 & .033 & .111 & .021 & .075 & .008 & .069 & .033 & .000 & .000 & .054 & .023 \\
\hline & B-100 & .864 & .930 & .909 & .943 & .841 & .883 & .895 & .886 & .925 & .942 & .000 & .000 & .902 & .955 \\
\hline & B-92 & .077 & .039 & .038 & .024 & .048 & .096 & .030 & .106 & .006 & .025 & .329 & .153 & .045 & .023 \\
\hline & B-76 & .000 & .000 & .000 & .000 & .000 & .000 & .000 & .000 & .000 & .000 & .671 & .847 & .000 & .000 \\
\hline & $H_{\mathrm{e}}$ & .246 & .134 & .171 & .111 & .280 & .211 & .193 & .205 & .140 & .112 & .447 & .262 & .184 & .089 \\
\hline \multirow[t]{4}{*}{ Pgm } & A-124 & .058 & .083 & .188 & .104 & .075 & .189 & .185 & .109 & .140 & .081 & .000 & .040 & .020 & .239 \\
\hline & A-100 & .904 & .841 & .754 & .799 & .884 & .750 & .781 & .841 & .760 & .845 & .610 & .420 & .880 & .761 \\
\hline & A-82 & .038 & .076 & .058 & .097 & .041 & .061 & .034 & .051 & .100 & .074 & .390 & .540 & .100 & .000 \\
\hline & $H_{e}$ & .180 & .282 & .396 & .345 & .213 & .401 & .357 & .281 & .395 & .275 & .482 & .536 & .217 & .368 \\
\hline \multirow[t]{4}{*}{ Skdh } & A-128 & .048 & .042 & .047 & .033 & .065 & .016 & .068 & .000 & .007 & .022 & .225 & .000 & .000 & .000 \\
\hline & $A-100$ & .912 & .845 & .773 & .917 & .892 & .937 & .873 & .971 & .926 & .897 & .663 & .813 & .973 & .700 \\
\hline & A-92 & .040 & .113 & .180 & .050 & .043 & .047 & .059 & .029 & .067 & .081 & .112 & .188 & .027 & .300 \\
\hline & $H_{e}$ & .164 & .273 & .370 & .157 & .201 & .120 & .232 & .057 & .139 & .190 & .504 & .308 & .054 & .425 \\
\hline
\end{tabular}


Table 2. - Measures of genetic variability and mean $\mathrm{F}_{\mathrm{IS}}$ values for the oak populations studied. Standard error in brackets.

\begin{tabular}{|c|c|c|c|c|c|}
\hline \multirow[t]{2}{*}{ Population } & \multirow{2}{*}{$\begin{array}{l}\text { Mean number } \\
\text { of alleles per locus }\end{array}$} & \multirow{2}{*}{$\begin{array}{l}\text { Percentage of } \\
\text { polymorphic loci }\end{array}$} & \multirow[t]{2}{*}{$F_{\text {IS }}$} & \multicolumn{2}{|c|}{ Mean heterozygosity } \\
\hline & & & & Direct-count & expected \\
\hline pt1 & $2.7(.2)$ & 90.9 & -.025 & $.290(.045)$ & $.283(0.044)$ \\
\hline pt3 & $2.7(.2)$ & 90.9 & .053 & $.304(.044)$ & $.321(0.050)$ \\
\hline pt4 & $2.6(.2)$ & 90.9 & .022 & $.309(.051)$ & $.316(0.055)$ \\
\hline pt5 & $2.5(.2)$ & 81.8 & .089 & $.204(.033)$ & $.224(0.037)$ \\
\hline rb2 & $2.3(.2)$ & 90.9 & .108 & $.222(.031)$ & $.249(0.035)$ \\
\hline rb3 & $2.5(.2)$ & 72.7 & .103 & $.192(.041)$ & $.214(0.048)$ \\
\hline rb4 & $2.8(.2)$ & 81.8 & .111 & $.225(.050)$ & $.253(0.058)$ \\
\hline rb5 & $2.8(.2)$ & 90.9 & .080 & $.208(.039)$ & $.226(0.040)$ \\
\hline Q. robur mean & $2.6(.1)$ & $85.4(3.6)$ & .091 & $.214(.001)$ & $.236(0.001)$ \\
\hline $\mathrm{cr} 1$ & $2.3(.2)$ & 90.9 & .079 & $.383(.052)$ & $.416(0.050)$ \\
\hline $\mathrm{pb} 2$ & $2.1(.3)$ & 45.5 & .192 & $.139(.041)$ & $.172(0.050)$ \\
\hline Q. pubescens mean & $2.5(.4)$ & $59.1(13.6)$ & .159 & $.174(.035)$ & $.206(0.034)$ \\
\hline General mean & $2.5(.1)$ & $83.1(3.4)$ & 081 & $.247(.017)$ & $.267(0.016)$ \\
\hline
\end{tabular}

accordance with the reported allelism (MÜLLER-STARCK and Ziene, 1991; ZANETTO et al., 1993; ZANETTO et al., 1994; BACILIERI et al., 1996a; SAMUEL et al., 1995; HerzoG, 1996). The fastest zones of activity for Got, Mdh, 6Pgdh and Pgi stained faintly, or were absent from many gels, and were thus excluded from the study.

Allele frequencies and expected levels of heterozygosity for the 11 polymorphic loci are given in Table 1 . In 7 loci, the most frequent allele was the same in all populations: exceptions are Dia-A, Gdh-A, Pgi-B and Pgm-A, where the allelic frequencies varied among species and/or populations. $Q$. cerris and $Q$. pubescens stands showed alleles not present in other populations, respectively Pgi-B ${ }^{76}$ and G3pdh-A ${ }^{94}$. Allele $6 \mathrm{Pgdh}-\mathrm{B}^{132}$ was absent from $Q$. petraea populations, alleles Dia- $\mathrm{A}^{122}$, Gdh-A ${ }^{120}$, Idh-A ${ }^{94}$, 6Pgdh-B ${ }^{84}$, Pgi-B ${ }^{124}$, Pgi-B ${ }^{100}$ from Q. cerris and alleles Got- $\mathrm{B}^{78}$, Idh- $\mathrm{A}^{136}$ and Skdh- $\mathrm{A}^{128}$ from $Q$. pubescens.

Genetic diversity values are given in Table 2. The mean number of alleles per locus showed little variation among populations, and in general the mean was 2.5. Q. pubescens showed a substantially lower percentage of polymorphic loci than the other species. A general excess of homozygotes was found in every population, except in population pt 1 of $Q$. petraea. $Q$. pubescens populations showed the higher values of $\mathrm{F}_{\mathrm{IS}}$, with an average of 0.159. Q. cerris was the species with the higher expected heterozygosity, but it also showed the lowest number of alleles per locus. The heterozygosity level of $Q$. pubescens was the lowest of all the populations examined (0.206).

As expected, most of the genetic variability was accounted for by the within population component $(85.6 \%)$, and $\theta$ computed among all the populations was $0.144(s d=0.040)$. Of this inter-population variability, the among species component was by far the most important and accounted for $13.1 \%(\theta=0.131 ; s d=0.05)$ of the total genetic variability. The Pgi and Dia loci were responsible for most of the variation $(\theta=0.500$ and 0.200 respectively). $Q$. cerris had a very different array of frequencies for these two loci compared with the other species. Excluding the two $Q$. cerris populations, the percent of variability among species was less than half $(\theta=0.050 ; s d=0.027)$.

Figure 2 shows results of the Principal Coordinate Analysis carried out on the matrix of Nei genetic distances. The first discriminant dimension (PcoA-1) accounts for the $75 \%$ of the variance and distinguishes very well $Q$. cerris group of populations from the others. Differentiation between $Q$. petraea, $Q$. robur and $Q$.pubescens is better seen on the second and third dimension plot, which account for $15 \%$ and $5 \%$ of the variance, respectively.

Differentiation between $Q$. robur and $Q$. petraea is around 5\% $(\theta=0.048 ; s d=0.033)$, but locus Dia $(\theta=$ 0.233 ) accounts for most of the variability. Dia is the only locus whose $\theta$ is greater than 0.04. Excluding Dia, $\theta$ calculated among these two species drops to 0.013 ( $\mathrm{sd}=0.004)$. Considering only the two locations ( $\mathrm{La}$ Mandria and Rocchetta Tanaro) where both $Q$. robur and $Q$. petraea were sampled, "geographic" and "species" differentiation can be compared. Differentiation among these 4 populations ( 2 species $\times 2$ locations) is around $5 \%(\theta=0.046 ; \mathrm{sd}=0.011)$ and is split in approximately equal parts between species $(\theta=0.025 ; \mathrm{sd}=0.010)$ and between locations $(\theta=0.026$; sd $=0.010)$. Values of $\theta$, and thus percent of variability, are not exactly additive because they are calculated on different total bases of genetic diversity (i.e. Rocchetta Tanaro populations have less expected heterozygosity than La Mandria populations, and $Q$. petraea have slightly less expected heterozygosity than $Q$. robur). When both species are collected in every location, according to BODENES et al. (1997), it is possible to distinguish between general differentiation among species $(\mathrm{Cg})$ and local differentiation among species $(\mathrm{Cl})$. $\mathrm{Cg}$ averages around $52 \%$ of the 

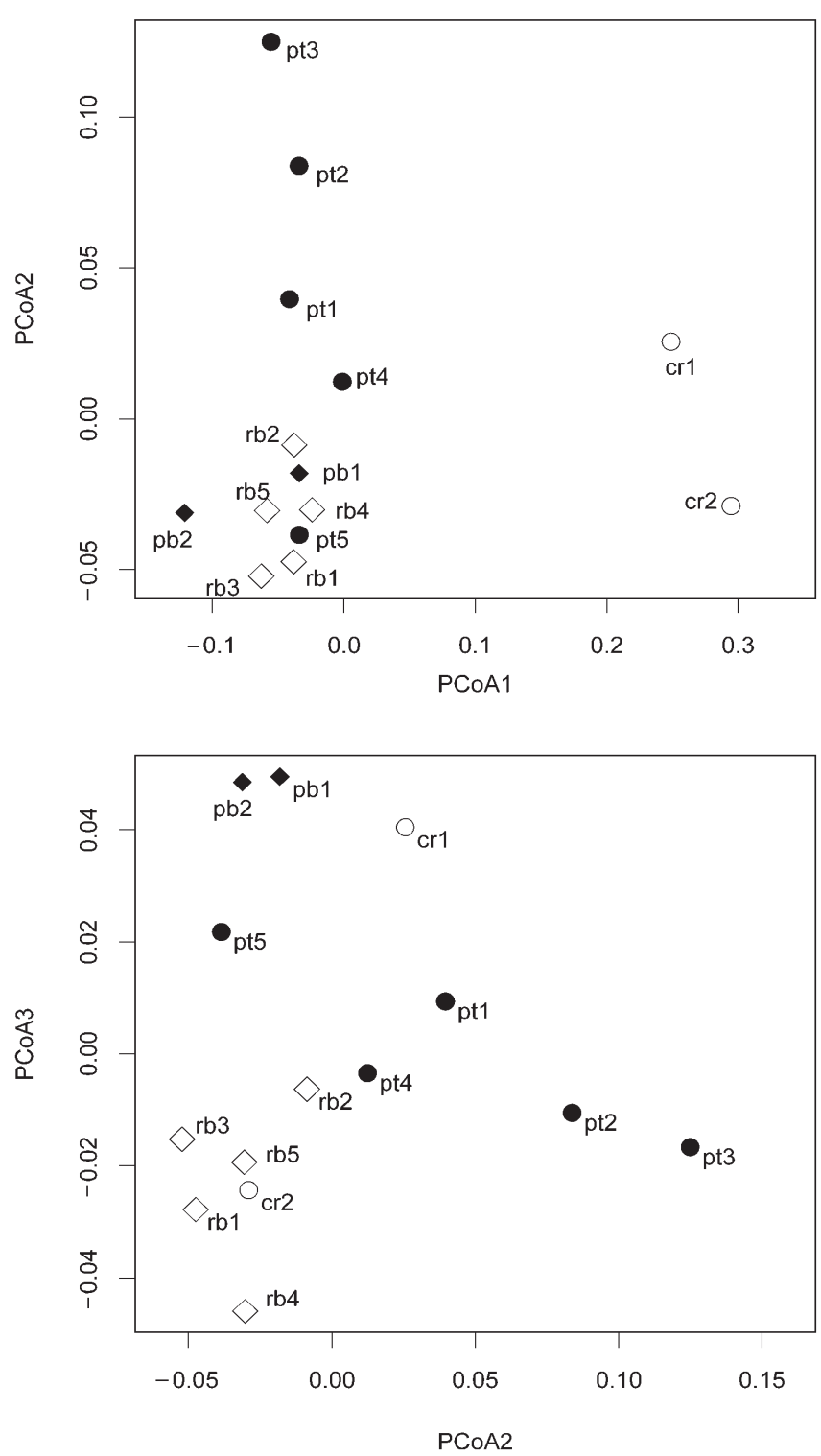

Figure 2. - Plot of Principal Coordinate Analysis computed on matrix of Nei genetic distance. Top: first principal coordinate vs. second. Bottom: second principal vs. third. Symbols indicate species: $(\bullet$ for $Q$. petraea, $\diamond$ for $Q$. robur, o for $Q$. cerris, $\diamond$ for $Q$. pubescens).

species differentiation, meaning that half of species differentiation is constant over all locations, but the pattern is quite different among loci. For Pgm, Mdh and Skdh general differentiation is more than $83 \%$, while for Got $93 \%$ of differentiation is local.

Figure 3 shows the genetic differentiation averaged across loci among the four populations. Geographic differentiation is very similar to species differentiation.

Variation among populations within $Q$. cerris species accounts for $8.5 \%(\theta=0.085$; sd $=0.025)$ of variability, while $\theta$ computed among $Q$. pubescens populations is 0.101 ( $\mathrm{sd}=0.042)$. $Q$. petraea has more than twice the population differentiation level than $Q$. robur $(\theta=0.077$; $\mathrm{sd}=0.028$ and $\theta=0.031 ; \mathrm{sd}=0.005$ respectively).

In total, 550 permutation tests have been calculated to test for linkage disequilibrium, and in 61 cases probability values have been less or equal to 0.05 (alpha). The

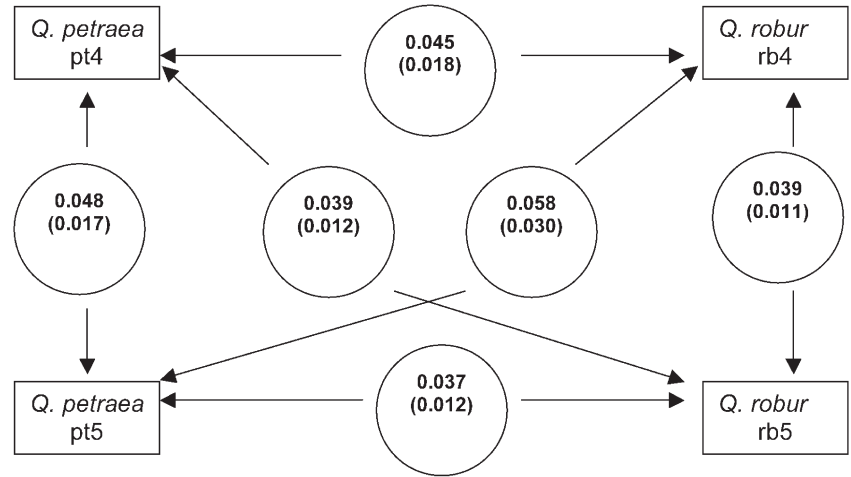

Figure 3. - Genetic differentiation averaged across loci among two populations of $Q$. petraea and two of $Q$. robur, sampled in two stands where both species are present. Standard error in brackets.

number of disequilibrium cases are significantly more numerous for $Q$. petraea (48 cases with $\mathrm{P} \leq 0.05$ out of $275)$ than for $Q$. robur (13 cases out of 275$)\left(\chi^{2}=21.3\right.$; $\mathrm{df}=1 ; \mathrm{P} \leq 0.001)$, and potential hybrid populations have a slightly greater proportion of significant cases of linkage disequilibrium than pure populations - but this result is not significant.

\section{Discussion}

The values of genetic diversity found in this study are substantially similar to those reported in the literature and scored through isozyme variation (MÜLLER-STARCK and ZIEHE, 1991; MÜlleR-STARCK et al., 1993; KIM et al., 1993; ZANeTto et al., 1993: MATTILA et al,. 1994; ZANETTO and KREMER, 1995). Differences among species have been clearly observed: $Q$. pubescens showed the lowest values of heterozygosity as well as of percentage of polymorphic loci, while $Q$. cerris had the highest heterozygosity level. $Q$. robur and $Q$. petraea showed similar values of genetic diversity but the latter exhibited more heterozygosity.

Lower levels of heterozygosity for isozyme markers in $Q$. pubescens as compared to $Q$. robur and $Q$. petraea have been described in Switzerland oak population (FINKELDEY and MÁTYÁs, 2003). Heterozygosity level observed in our $Q$. pubescens populations is even lower than that observed in swiss populations ( 0.206 vs 0.215 ).

The deviation from random mating, expressed as the inbreeding coefficient $\mathrm{F}_{\text {IS }}$, was significant and quite different among species: $Q$. pubescens had the highest value (0.159), suggesting high levels of inbreeding and reduced gene exchange, while $Q$. petraea showed observed heterozygosity quite similar to Hardy-Weinberg expectations $\left(\mathrm{F}_{\text {IS }}=0.040\right)$.

In the choice of stands to be used for production of high quality seeds, the homozygosity level should be taken into consideration, due to the negative effect of self-fertilization on seed quality.

Generally, in forest species levels of homozygosity (and thus $\mathrm{F}_{\mathrm{IS}}$ ) tend to decrease in mature ages classes because of the effect of selection against homozygotes (Rossi et al., 1996). These results in adults could suggest even higher values in younger classes, with the 
probable presence of mating between relatives, but these result is different to what expected for $Q$. pubescens, because the sampled populations for this species are quite huge with high density of adult individuals (potential reproducers). This situation should favour high levels of pollen flow with consequently high outcrossing rates that should limit homozygote excess. So, these results need further investigations. In particular, an analysis of genetic variability in seeds should clarify if high levels of homozygotes are effectively present in younger age classes. In fact, only very high values of $\mathrm{F}_{\text {IS }}$ should be dangerous, because even moderate levels of homozygote excess can be purged by selection during the growth of the plants (MÜLLER-STARCK and ZIEHE, 1991). Heterozygotes are in fact more resistant to environmental stresses (HERTEL et al., 1994). Although all the stands included in the study are adult, none of them is really old and, in general, young individuals are present. Of course, in the choice of stands to be used for production of high quality seeds, the homozygosity level should be taken into consideration due to the negative effect of self-fertilization on seed quality.

Caution is needed in the interpretation in terms of adaptability of the population studies of our results, because the relation between variability at neutral loci and adaptive ones has been extensively discussed during recent years. REED and FRANCKHAM (2001) performed a metanalysis of the correlation between molecular and quantitative measures and find only a weak correlation between molecular and quantitative traits $(\mathrm{r}=0.217)$, with a completely absence of relationship between neutral variation and life history traits $(\mathrm{r}=-0.11)$ and with heritability, that is considered the best indicator of adaptive potential. Recently other studies confirmed this trend, both in experimental studies (BEKESSY et al., 2003) and in computer simulations (CARvajal-Rodriguez et al., 2005). So to assess the amount of adaptive variability present in our populations further studies on quantitative traits are needed.

The study confirmed the low level of genetic variability among the studied species: only $Q$. cerris populations can be distinguished on the basis of isozyme genotype. On the contrary, species belonging to the subg. Lepidobalanus are genetically very similar. Principal Coordinate Analysis showed a good separation of $Q$. cerris and $Q$. pubescens while $Q$. robur and $Q$. petraea still remain closer. These results are in agreement with those of other authors, where only $2 \%$ out of 2,800 RAPD tested loci differentiated the two species (BODENES et al., 1997). In other studies, non-overlapping ranges of allele frequencies for $Q$. petraea and $Q$. robur populations have been observed at particular isozyme gene loci (e.g. IdhB, Pgm-A: Zanetto et al., 1994; Hertel and Degen, 2000; FINKELDEY, 2001) confirming that the observed morphological differentiation coincides with genetic differentiation between the species. Furthermore the locus Got-2 has been reported as a good species-specific marker (SAMUEL et al., 1995), while in the present study this feature was not proved. Probably, our Got-B locus corresponds with the little polymorphic Got-B locus reported by MÜLLER-STARCK et al. (1993) and not with Got-2 locus of Samuel and collaborators. The difference in the Got results can be explained by the different gel system used: while SAMUEL and collaborators separated Got isozymes in a strongly basic gel, we used a gel system at $\mathrm{pH}$ 7.0. Among the isozymes tested in this study, Pgi-B and Dia-A proved to be the most efficient in discriminating among all the species tested, while differentiation between $Q$. robur and $Q$. petraea could be better pursued using allelic frequencies at locus Dia-A. Principal Coordinate Analysis was found to be more useful for separating species, namely $Q$. robur and $Q$. petraea. In such way it was possible to get an optimal discrimination, notwithstanding the scarce level of differentiation between species, which, in mixed populations, is similar to that scored among populations belonging to the same species. Quantification of general and local differentiation confirms that only about $50 \%$ of the genetic differences between $Q$. robur and $Q$. petraea are constant, while the remaining $50 \%$ is due to variation among populations. These values are very similar to those reported by BoDENES et al. (1997).

Microsatellites seem to be more informative than isozymes to discriminate between $Q$. robur and Q. petraea. MUIR et al. (2000) were able to discriminate between these two species using 20 microsatellite markers, while PETIT et al. (2003) using chloroplast markers were not able to discriminate between diferent white oaks species.

\section{Acknowledgments}

The technical assistance of Mr. A. VARETTO is highly appreciated. The work was partly funded by the PIEDMONT REGION (Assessorato Agricoltura e Foreste).

\section{References}

BAcilieri, R., G. Roussel and A. Ducousso (1993): Hybridization and mating system in a mixed stand of sessile and pesuncolate oak. Ann. Sci. For. 50 (Suppl. 1): 122-127.

BACILIERI, R., T. LABBÉ and A. Kremer (1994): Intraspecific genetic structure in a mixed population of Quercus petraea (Matt.) Liebl. and Quercus robur L. Heredity 73: $130-141$.

Bacilieri, R., A. Ducousso and A. Kremer (1995): Genetic, morphological and phenological differentiation between Quercus petraea (Matt.) Liebl. and Quercus robur L. in a mixed stand of Northwest of France. Silvae Genetica 44: 1-10.

Bacilieri, R., A. Ducousso and A. Kremer (1996a): Comparison of morphological characters and molecular markers for the analysis of hybridization in sessile and pedunculate oak. Ann. Sci. For. 53: 79-91.

Bacilieri, R., A. Ducousso, R. J. Petit and A. Kremer (1996b): Mating system and asymmetric hybridization in a mixed stand of European oaks. Evolution 50: 900-908.

Bekessy, S. A., R. A. Ennos, M. A. Burgman, A. C. NewTON and P. K. ADES (2003): Neutral DNA markers fail to detect genetic divergence in an ecologically important trait. Biological Conservation 110: 267-275.

Bodenes, C., S. JoAndet, F. LAigret and A. Kremer (1997): Detection of genomic regions differentiating two closely related oak species Quercus petraea (Matt.) Liebl. and Quercus robur L. Heredity 78: 433-444. 
Bruschi, P., G. G. Vendramin, F. Bussotti and P. Grossoni (2000): Morphological and Molecular differentiation between Quercus petrea (Matt.) Liebl. and Quercus pubescens Willd (Fagaceae) in Northern and Central Italy. Annals of Botany 85: 325-333.

Bruschi, P., G. G. Vendramin, F. Bussotti and P. Grossoni (2003): Morphological and Molecular Diversity Among Italian Populations of Quercus petraea (Fagaceae). Annals of Botany 91: 707-716.

Carvajal-Rodriguez, A., E. Rolán-Alvarez and A. CABalLERO (2005): Quantitative variation as a tool for detecting human-induced impacts on genetic diversity. Biological Conservation 124: 1-13.

CoART, E., V. LAMote and M. De Loose (2002): AFLP markers demonstrate local genetic differentiation between two indigenous oak species Quercus robur L. and Quercus petraea (Matt.) Liebl. in Flemish populations. Theor. Appl. Genet. 105: 431-439.

Dupouey, J. L. and V. BADEAU (1993): Morphological variability of oaks (Quercus robur L., Quercus petraea (Matt.) Liebl., Quercus pubescens Willd.) in northeastern France. Annales des Sciences Forestières 50 (Suppl. 1): $35-40$.

Dutech, C., V. L. Sork, A. J. Irwin, P. E. Smouse and F. W. DAVIS (2005): Gene flow and fine-scale genetic structure in a wind-pollinated tree species Quercus lobata (Fagaceae) American Journal of Botany 92: 252-261.

Ellstrand, N. C. and D. R. Elam (1993): Population genetic consequences of small population size: implication for plant conservation. Annual Review of Ecology and Systematics 24: 217-242.

Fenaroli, L. and G. Gambi (1976): Alberi. Museo Tridentino di Scienze Naturali, Trento, pp. 320-393.

FINKELDEY, R. (2001): Genetic variation of oaks (Quercus spp.) in Switzerland. 2. Genetic structures in "pure" and "mixed" forests of pedunculate oak $(Q$. robur L.) and sessile oak (Q. petraea (Matt.) Liebl.). Silvae Genetica 50: $22-30$.

FinkelDEY, R. and G. MÁTyÁs (2003): Genetic variation of oaks (Quercus spp.) in Switzerland. 3. Lack of impact of postglacial recolonization history on nuclear gene loci. Theor. Appl. Genet. 106: 346-352.

Gömöry, D., I. YAKOVLEv, P. Zhelev, J. JEDINÁKovÁ and L. PAULE (2001): Genetic differantiation of oak population within the Quercus robur/Quercus petraea complex in Central and Eastern Europe. Heredity 86: 557-563.

HERTEL, H., I. ZASPEL and D. R. EISENHAUER (1994): Investigations about vitality and genetic structure in oak stands. In: Proceedings of International Symposium on environmental constraints and oaks: ecological and physiological aspects. Nancy, France, 9 pp.

Hertel, H. and B. Degen (2000): Unterscheidung von Stiel- und Traubeneichen (Quercus robur L. und Q. petraea [Mattuschka] Liebl.) mit Hilfe von genetischen und morphologischen Merkmalen. Forest Snow and Landscape Research, Birmensdorf 75, 169-183.

HERzoG, S. (1996): Genetic inventory of European oak populations: consequences for breeding and gene conservation. Ann. Sci. For. 53: 783-793.

KIM, Z. S., S. W. LEE and J. O. HyUN (1993): Allozyme variation in 6 native oak species in Korea. In: KREMER, A., SAvill, P. S. and Steiner, K. C. (eds). Genetics of oaks, Elsevier-INRA, Paris, pp. 253-260.

KLEINSCHMiT, J. (1993): Intraspecific variation of growth and adaptative traits in European oak species. Annales des Sciences Forestières 50 (Suppl. 1): 166-185.
Kleinschmit, J. R. G., R. BAcilieri, A. Kremer and A. Roloff (1995): Comparison of morphological and genetic traits of Pedunculate Oak $(Q$. robur L.) and Sessile Oak (Q. petraea (Matt.) Liebl.). Silvae Genetica 44: 256-269.

Kremer, A. and A. ZANETTO (1997): Geographical structure of gene diversity in Quercus petraea (Matt.) Liebl. II. Multilocus patterns of variation. Heredity 78: $476-489$.

Kremer, A., J. Kleinschmit, J. Cottrell, E. P. Cundall, J. D. Deans, A. Ducousso, A. O. König, A. J. Lowe, R. C. Munro, R. J. Petit and B. R. Stephan (2002a): Is there a correlation between chloroplastic and nuclear divergence, or what are the roles of history and selection on genetic diversity in European oaks? Forest Ecology and Management 156: 75-87.

Kremer, A., J. L. Dupouey, J. D. Deans, J. Cottrell, U. Csaikl, R. Finkeldey, S. Espinel, J. Jensen, J. Kleinschmit, B. van Dam, A. Ducousso, I. Forrest, U. L. DE Heredia, A. J. Lowe, M. Tutkova, R. C. Munro, S. SteinhofF and V. BADEAU (2002b): Leaf morphological differentiation between Quercus robur and Quercus petraea is stable across western European mixed oak stands Annals of Forest Science 59: 777-787.

Le Corre, V., G. Roussel, A. Zanetto and A. Kremer (1998): Geographical structure of gene diversity in Quercus petraea (Matt.) Liebl. III . Patterns of variation identified by geostatical analyses. Heredity 80: 464-473.

LEDIG, F. T. (1988): The conservation of diversity of forest trees. Biosciensce 38: 471-479.

LEDIG, F. T. (1992): Human Impacts on Genetic Diversity in Forest Ecosystems. Oikos 63: 87-108.

Mattila, A., A. PAKkanen, P. VAKKaRI and J. Raisio (1994): Genetic variation in English Oak (Quercus robur) in Finland. Silva Fennica 28, 251-156.

MANos, P. S., J. J. DoYLE and K. C. Nixon (1999): Phylogeny, Biogeography and Processes of Molecular Differentiation in Quercus Subgenus Quercus (Fagaceae). Molecular Phylogenetics and Evolution 12: 333-349.

Muir, G., C. C. Fleming and C. Schlötterer (2000): Species status of hybridizing oaks. Nature 405: 1016.

Muir, G., A. J. Lowe, C. C. Fleming and C. VoGL (2004): High Nuclear Genetic Diversity, High Levels of Outcrossing and Low Differentiation Among Remnant Populations of Quercus petraea at the Margin of its Range in Ireland. Annals of Botany 93: 691-697.

Müller-StarcK, G. and M. ZIehe (1991): Genetic variation in populations of Fagus sylvatica L., Quercus robur L. and $Q$. petraea Liebl. in Germany. In: MÜLLERStARCK, G. and Ziehe, M. (eds). Genetic variation in European populations of forest trees. Sauerländer's Verlag, Frankfurt, pp. 125-140.

Müller-Starck, G., S. HerzoG and H. H. Hattemer (1993): Intra- and interpopulational genetic variation in juvenile populations of Quercus robur L. and Quercus petraea Liebl. In: KREMER, A., SAVILL, P. S. and STEINER, K. C. (eds). Genetics of oaks. Elsevier-INRA, Paris, pp. 233-244.

NEI, M. (1978): Estimation of average heterozygosity and genetic distance from a small number of individuals. Genetics 89: $583-590$.

NIXON, K. C. (1993): Infrageneric classification of Quercus (Fagaceae) and typification of sectional names. In: KREMER, A., SAVILl, P. S. and Steiner, K. C. (eds). Genetics of oaks. Elsevier-INRA, Paris, pp. 25-34. 
Petit, R. J., S. Brewer, S. Bordács, K. Burg, R. CheddADi, E. CoArt, J. Cottrell, U. M. Csaikl, B. van Dam, J. D. Deans, S. Espinel, S. Fineschi, R. Finkeldey, I. Glaz, P. G. Goicoechea, J. S. Jensen, A. O. König, A. J. Lowe, S. F. Madsen, G. Mátyás, R. C. Munro, F. PopesCU, D. Slade, H. Tabbener, S. G. M. de Vries, B. Ziegenhagen, J. L. de BeAulieu and A. Kremer (2002): Identification of refugia and post-glacial colonisation routes of European white oaks based on chloroplast DNA and fossil pollen evidence. Forest Ecology and Management 156: 49-74.

Petit, R. J., C. Latouche-Hallé, M. H. Pemonge and A. KREMER (2002): Chloroplat DNA variation of oaks in France and the influence of forest fragmentation on genetic diversity. Forest Ecology and Management 156: 115-129.

Petit, R. J., C. Bodénès, A. Ducousso, G. Roussel and A. Kremer (2003): Hybridization as a mechanism of invasion in oaks. New Phytologist 161: 151.

Ponton, S., J. L. Dupouey and E. Dreyer (2004): Leaf morphology as species indicator in seedlings of Quercus robur L. and $Q$. petraea (Matt.) Liebl.: modulation by irradiance and growth flush. Annals of Forest Science 61: 73-80.

R Development Core Team (2004): R: a language and environment for statistical computing. R Foundation for Statistical Computing, Vienna, Austria. 3-900051-00-3, http://www.R-project.org.

REED, D. H. and R. Frankham (2001): How closely correlated are molecular and quantitative measures of genetic variation? A meta-analysis. Evolution 55: 1095-1103.

Rossi, P., G. G. VENDRAMIN and R. GIANNINI (1996): Estimation of mating system parameters in two Italian natural populations of Fagus sylvatica. Canadian Journal of Forest Research 26: 1187-1192.

Rushton, B. S. (1993): Natural hybridization within the genus Quercus L. In: KREMER, A., SAVILL, P. S. and Steiner, K. C. (eds). Genetics of oaks. Elsevier-INRA, Paris, pp. 73-90.

SAMUEL, R. (1999): Identification of hybrids between Quercus petraea and $Q$. robur (Fagaceae). Results obtained with RAPD markers confirm allozyme studies based on the Got-2 locus. Plant Syst. Evol. 217: 137-146.
SAMUel, R., W. PINSKER and F. EHRENDORFER (1995): Electrophoretic analysis of genetic variation within and between populations of Quercus cerris, Q. pubescens, $Q$. petraea and $Q$. robur (Fagaceae) from Eastern Austria. Botanica Acta 108: 290-299.

Streiff, R., A. Ducousso, C. Lexer, H. Steinkellner, J. Gloessl and A. KREMER (1999): Pollen dispersal inferred from paternity analysis in a mixed oak stand of Quercus robur L. and Quercus petraea (Matt.) Liebl. Molecular Ecology 8: 831-841.

Swofford, D. L. and R. B. SELANDER (1981): BIOSYS-1: a Fortran program for the comprehensive analysis of electrophoretic data in population genetics and systematics. J. Hered. 72: 281-283.

Venables, W. N. and B. D. RIPLey (1997): Modern Applied Statistics with S-PLUS. Second Edition. Springer, 548 pages.

WEEDEN, N. F. (1984): Distinguishing among white seeded bean cultivars by means of allozyme genotypes. Euphytica 33: 199-208.

Weir, B. S. and C. C. Cockerham (1984): Estimating Fstatistics for the analysis of population structure. Evolution 38: 1358-1370.

WeIR, B. S. (1996): Genetic data analysis II. Method for discrete Population Genetic Data. Sinauer, Sunderland MA, $376 \mathrm{pp}$.

WendeL, J. and N. F. WeEden (1989): Genetics of plant isozymes. In: Soltis, D. E. and Soltis, P. S. (eds). Isozymes in Plant Biology. Dioscorides Press, Portland, pp. $46-72$.

Zanetto, A., A. Kremer and T. LABbÉ (1993): Differences in genetic variation based on isozymes of primary and secondary metabolism. In: Kremer, A., SAVILL, P. S. and Steiner, K. C. (eds). Genetics of oaks. Elsevier-INRA, Paris, pp. 245-252.

Zanetto, A., G. Roussel and A. Kremer (1994): Geographic variation of inter-specific differentiation between Quercus robur L. and Quercus petraea (Matt.) Liebl. Forest Genetics 1: 111-123.

ZanetTo, A. and A. KREMer (1995): Geographical structure of gene diversity in Quercus petraea (Matt.) Liebl. I. Monolocus patterns of variation. Heredity $\mathbf{7 5}$ : 506-517. 